centre for Safe Community-work in Norway since 2004, and also functions as an "International Safe Community Support Centre".

An updated Law of Public Health was introduced in Norway in 2012 where preventive efforts were given a broader attention. The same focus was echoed in the health sector reform, the Strategy for Universal Accessibility and the Planning- and Building Act. These laws and regulations give Norway a supportive framework, and a potential to gain interest for safety work on community level.

Results A new model for community safety has been developed based on Norwegian laws and regulations and the Safe Community concept. The national model is developed to meet the specific political and administrative demands on Norwegian municipalities in terms of health, safety, plan processes etc. The model is based on long term, systematic, evidence based safety efforts. It promotes inter- and cross-sector cooperation, sustainable projects and broad participation from all parts of society. The model is a useful tool for communities turning national policies into local realities.

Conclusion The national model was launched in 2014. It has motivated new municipalities to join the national network and put community safety on the local agenda. The Norwegian national network includes nationally as well as internationally designated communities. I all 22 municipalities and 2 counties are designated, and another 15-20 are part of the network but not yet designated. NSFs work with community safety is specifically mentioned in the new National Program for Public Health.

\section{THE SAFER HOMES PROGRAMME}

Sheila Merrill. The Royal Society for the Prevention of Accidents (RSPA)

\subsection{6/injuryprev-2016-042156.230}

Background Home accidents are a leading cause of death and injury in the UK. Falls among older people lead to over 4 million hospital bed days each year. Almost 1 million children require emergency care following home accidents. Partnership working is vital to address this key public health issue.

Description The Safer Homes Programme provided a package of consultancy, training and intervention across 30 local authority areas with higher than average hospital admission rates for accidents. The programme helped partners, who included local authorities, home improvement agencies, charities, Fire Services and NHS, to develop strategic plans and business cases. It trained local practitioners to plan, implement and evaluate community interventions including home safety checks, falls and burns interventions and advice to vulnerable families.

Results Over 740 staff received the home safety training. The community interventions and advice given to families reached over 166,000 people. An independent evaluation by ICF International found increased home safety awareness among staff; improved partnership working and the development of clear injury prevention strategies. Training increased confidence of staff to raise awareness among client families. Families demonstrated practical safety improvements and behaviour change. One area reported a $12 \%$ drop in hospital admissions due to falls.

Conclusions The programme raised the profile of accident prevention among local partners at a crucial time of change as well as making homes safer within their local communities. Learning about effective strategic development and local delivery of interventions has been shared between partners and more widely to improve practice.

\section{SAFETY WEEK SKI MUNICIPALITY, NORWAY}

Liv Marit Bølset. Health Promotion Adviser, Ski Municipality, Norway

10.1136/injuryprev-2016-042156.231

Background In 1991 it was a very terrible accident with a small bus. Parents with many children were hurts and no one used seatbelts. Our public health nurses started to ask the parents about seatbelts and this was the start of the Safety Week. Since then the Safety Week has developed into a judge arrangement once a year. This is also the beginning of Safe community in Ski.

Methods This is a cross sectorial work with many professionals from health, education, police, fire department and doctors. Three working groups organise the lessons for the target groups. The lessons are given during 7 days and for seniors there are several courses over a long period. The target groups are: parents for children up to 18 months, students in $8^{\text {th }}$ degrees and minorities groups, seniors and employees. The themes for the lessons are: first aid, road safety, fire prevention and domestics' violence. Results Safety Week is held once a year in September while more simplified days throughout the year, whether it is linked with Safety Week. Most of the teaching is both theoretical and practical. About 1000 inhabitant distributed among the various target groups participating in the teaching organised by Safety Week each year. The youth in $8^{\text {th }}$ degrees are new every year. Instruction for this group results in a systematic training in the population. The schools follow up the teaching.

Conclusions Feedback from audiences and from professionals who teach shows that teaching is of high quality and is very relevant.

\section{ESTABLISHMENT OF THE FIRST RUSSIAN INJURY REGISTRY IN SHENKURSK}

${ }^{1,2}$ Alexander V Kudryavtsev, ${ }^{3}$ Vasilii Anfimov, ${ }^{4}$ Kees Jan Verhage, ${ }^{1,5,6}$ Andrej M Grjibovski. ${ }^{1}$ International School of Public Health, Northern State Medical University, Arkhangelsk, Russia; ${ }^{2}$ Department of Community Medicine, UT - The Arctic University of Norway, Tromsø, Norway; ${ }^{3}$ Shenkursk Central District Hospital Named After N.N. Priorov, Shenkursk, Russia; ${ }^{4}$ Norwegian Safety Promotion Centre, Harstad, Norway; ${ }^{5}$ Department of Preventive Medicine, International Kazakh-Turkish University, Turkestan, Kazakhstan; ${ }^{6}$ Department of International Public Health, Norwegian Institute of Public Health, Oslo, Norway

\subsection{6/injuryprev-2016-042156.232}

Background External causes of death are the second main killers in several parts of Russia. However, no systematic collection and analysis of injury data exists hindering development of effective prevention. Our aim was to establish an injury registry in Shenkursk (Arkhangelsk region) and present the structure of injuries in January June 2015.

Methods All injuries admitted to Shenkursk district hospital during 1.1.2015 30.6.2015 were registered using standard form. It includes items on type, place, time, preceding circumstances, and mechanism of accident, mechanism of injury and socio-demographic data of the injured. Distributions of injuries across these variables were used to identify typical injury cases and risky circumstances.

Results Altogether, 673 non-fatal injury cases were recorded (76\%). Injuries to the head (21.6\%), injuries to the wrist and hand $(18.3 \%)$, injuries to the knee and lower leg $(10.7 \%)$ were the most common. By severity, 64\%, 28.7\% and 6.2\% of injuries were minor, moderate, and serious, respectively, 2 cases were severe, and one was critical. Hospitalisation rate was 9.2\%. 